\title{
RELATIONSHIP BETWEEN CHILDREN'S ENERGY AND
}

\section{MOTHER-CHILD INTERACTIONS}

\section{REETU DEVI ${ }^{1}$, SHANTI BALDA $^{2}$ \& PINKI RANI ${ }^{3}$}

${ }^{1}$ Research Scholar, Department of Human Development and Family Studies, College of Home Science,

CCS Haryana Agricultural University, Hisar, Haryana, India

${ }^{2}$ Professor, Department of Human Development and Family studies, College of Home Science,

CCS Haryana Agricultural University, Hisar, Haryana, India

${ }^{3}$ Assistant Professor, Department of Home Science at FGM Government College, Adampur, Punjab, India

\section{ABSTRACT}

The temperament can be defined as innate or early-appearing individual differences in emotional and behavioral responses. The present study was conducted in Hisar District in Haryana state. 50 boys and 50 girls in the age group of 6 to 8 years and their mothers were selected randomly from village Dobhi. Hence, the total sample for the study was 200 (50 boys and 50 girls and 100 mothers). There were two types of variables in the study, i.e. independent and dependent variable. A dependent variable is a variable presumed to be affected by one or more independent variables. Mother-child Interaction was taken as the dependent variable. Inventory was prepared and used. The result revealed that Children's emotionality was positively significantly correlated with maternal affection $(0.22 *)$ and responsiveness $(0.21 *)$ and a positive trend was also observed for maternal teaching.

KEYWORDS: Temperament, Emotions, Sociability, Warmth, Tolerance, Affection \& Encouragement

Received: Apr 06, 2018; Accepted: Apr 27, 2018; Published: May 08, 2018; Paper Id.: IJESRJUN20189

\section{INTRODUCTION}

Temperament generally is conceptualized as an innate predisposition in reactivity and self-regulation. It reflects individual differences in excitability of behavioral and physiological systems as well as emotional reactivity and the regulation of this reactivity (Komsi et al., 2008). Temperament is considered to be relatively consistent over time, having a strong genetic component (Zetner and Bates, 2008).

The child with an easy temperament is always cheerful, easily accepts new foods, and makes little fuss about ordinary frustration and smiles at everyone. The child with a difficult temperament does not establish regular eating and sleeping patterns, requires a long time to new routines, is happy and unfriendly, is likely to throw tantrums at the slightest frustration. The child with slow-to-warm temperament does not take most new offerings the first time but given time, the child will become interested in and even enjoy, these additions to his or her life. These children are mild in their reaction and they are somewhat irregular inhabits.

Rothbart and Bates (2006) reported that if one child is described as cheerful and upbeat, another can be described as active and energetic, and still others as calm, cautions, persistent, or prone to angry outbursts. All these behavior styles are referred to as temperament, which is early appearing, stable over time and there are 
individual differences in these styles.

Three main dispositional characteristics - inhibition/sociability, difficult temperament, and activity level have been found to influence children's interactions with others, particularly mother-child interaction. Inhibitions refer to a timid, vigilant and the restrained behavior style when faced with novel stimuli. Activity refers to the intensity and pace of a child's behavior and speech. Difficult temperament refers to the frequent and intense expression of negative emotions (Thomas and Chess, 1989).

Sanson and Rothbart (2002) revealed that child's behavior may be seen as the simple and direct outcome of their upbringing. With the second child, management strategies that worked well with the first child may not be effective. Problems experienced with the first child (in feeding, sleeping, coping with strangers) may not exist with the second, but new problems may arise. Such experiences suggest strongly that "nature" as well as "nurture" influences child development, that children differ from each other from very early in life, and that these differences have important implications for parent-child interaction.

Carolyn and Sheila (2009) examined child temperament and its relationship with child behavior problems and quality of mother-child interactions. Children who were perceived by their mothers as more active with a low attention span tended to have more behavior problems and to be more non accepting or noncompliant in their interactions with their mothers. Mothers of active children, in turn, were described as more negative and non-accepting in their responses to their children. Hence, mother-child interaction is influenced by the temperament of children and vice-versa.

\section{OBJECTIVE}

To study the correlations between Children's energy and mother-child interactions.

\section{METHODOLOGY}

The present study was conducted in Hisar District of Haryana State. From Hisar district village Dobhi was selected purposively. 50 boys and 50 girls in the age group of 6 to 8 years and their mothers were selected randomly from village Dobhi. Hence, the total sample for the study was 200 (50 boys and 50 girls and 100 mothers). There were two types of variables in the study, i.e. independent and dependent variable. A dependent variable is a variable presumed to be affected by one or more independent variables. Mother-child Interaction was taken as the dependent variable. Inventory was prepared and used.

\section{RESULTS AND DISCUSSIONS}

\section{Correlations between Children's Energy and Mother-Child Interactions}

Correlations were computed between the temperament of children and domains of mother-child interaction. Different domains of mother-child interaction were affection, responsiveness, encouragement and teaching.

As depicted in Table 1, Children's energy was positive and significantly correlated with maternal responsiveness $\left(0.18^{*}\right)$ and a positive trend was observed for maternal affection and encouragement. 


\section{Table 1: Correlation's Between Children's Energy and Domains of Mother Child Interaction}

\begin{tabular}{|l|c|}
\hline \multirow{2}{*}{$\begin{array}{c}\text { Domains of Mother- } \\
\text { Child Interaction }\end{array}$} & $\begin{array}{c}\text { Temperament } \\
\text { of Children }\end{array}$ \\
\cline { 2 - 2 } & Energy \\
\hline Affection & 0.16 \\
\hline Responsiveness & $0.18^{*}$ \\
\hline Encouragement & 0.17 \\
\hline Teaching & 0.03 \\
\hline
\end{tabular}

Note: *Significant at $5 \%$ level.

\section{DISCUSSIONS}

The relationship between temperament of child and mother-child interaction was also studied. Results revealed that sociable and rhythmic children was likely to have affectionate, responsive, encouraging mothers who were also more involved in teaching. Energetic children had affectionate, responsive and encouraging mothers. Happy children were likely to have affectionate and responsive mothers involved in teaching. Less Distractible children were likely to have responsive mothers involved in teaching.

\section{CONCLUSIONS}

Thus, it can be said that easy children were likely to have a positive interaction with their mothers. In other words, it seems that easy children are easily brought up. It can be inferred from these results that there tend to be good 'fit' between children's temperament and mother-child interaction. There is a bi-directional relationship between child's temperament and mother-child interaction. These findings get support from the literature reviewed.

Rothbart and Bates (2006) reported that parental functioning and the family environment are likely to influence child temperament. Temperament, in turn, is likely to mold individual adaptation to the environment.

\section{REFERENCES}

1. Allard, L. T. and Hunter, A. 2014. Developing a strong, beneficial relationship with your child. Retrieved from $<$ http://csefel.vanderbilt.edu/resource/parenting-difficult-child.

2. Anonymous.2011.Temperament and Parenting - Temperament.com. Retrieved from https://www.b-di.com/temperament. comfaqs.html

3. Costa, P.T. and McCare, R.R. 2000. Nature over nurture: Temperament, personality and life span development. Journal of Personality and Social Psychology, 78 (1): 173-186.

4. Griggs, M. S., Gagnon, S.G., Huelsman, T. J., Kidder-Ashley, P. and Ballard, M. 2009. Student-teacher relationships matter: Moderation influences between temperament and preschool social competence. Psychology in the Schools.46: 553-566.

5. Kashyap, I. 2013. Temperament and development domains, Unpublished Masters Thesis, HDFS, CCSHAU, Hisar.

6. Kathy, K. O.2002. Understanding Your Child's Temperament. Family Life Month Packet. 5: 1-2.

7. Komsi, N., Räikkönen, K., Heinonen, K., Pesonen, A., Keskivaara, P., Järvenpää, A., \& Strandberg, T. E. (2008).Transactional development of parent personality and child temperament. European Journal of Personality, 22(6), 553-573. doi:10.1002/per.690 
8. Kohnstamm, G. 1989. Temperament in Childhood: cross-cultural and sex differences. In G.A. Kohnstamm, J.E. Bates and M.K. Rothbart (Eds), Temperament in Childhood (pp.483-508). New York: Wiley.

9. Kumari, V. 2011.Temperament, interpersonal competence and socio-metric status of 6 to 8 years old children. Ph.D. Dissertation. Department of Human Development and Family Studies, I.C. College of Home Science, CCS Haryana Agricultural University, Hisar.

10. Malhotra, S. and Malhotra, A. 1988.Malhotra's Temperament Schedule. National Psychogical Corporation. Agra.

11. Prior, M., Smart, D., Sanson, A.V. and Oberklaid, F. 1993.Sex differences in psychological adjustment from infancy to 8 years. Journal of the American Academy of Child and Adolescence Psychiatry, 32 : 291-304.

12. Abu-Hashim, M. S. D., A. Salama, and A. Garbout. "Characterization of Soil-Root Interactions using Medical X-Ray Computed Tomography Technique." International Journal of Agricultural Science and Research (IJASR) 5.5 (2015): 159-170.

13. Rothbart, M. K. and Bates, J. 2006. Temperament. In W. Damon (Series Ed), \& N. Eisenberg (Vol. Ed), Handbook of child psychology: Social emotional and personality development (Vol. 3, 6th ed., pp. 99-166). New York: Wiley.

14. Sanson, A. and Rothbart, M. K. 2002.Child temperament and parenting. In M. Bornstein (Ed.), Applied and practical parenting (Vol. 4, pp. 299-321). Mahwah, NJ: Lawrence Erlbaum.

15. Allawi, Ali Abdulmajid Dyab, Jawad Ibrahim Rasheed, and Mohammed Younus Naji Al Atbee. "Relationship of Fetuin-A and Coronary artery calcification in hemodialysis patients." Age 55.6: 10.

16. Steinberg, L. 2004. The 10 basic principles of good parenting. New York, NY: Simon \& Schuster Paperbacks.

17. Zentner, M., \& Bates, J. E. (2008). Child temperament: An integrative review of concepts, research programs, and measures. European Journal of Developmental Science, 2(1-2), 7-37.

18. Walker, S., Berthelsen, D. and Irving, K. 2001. Temperament and peer acceptance in early childhood: Sex and social status differences. Child Study Journal, 31 : 177-192.

19. Vig., D. and Jaswal, J.S. 2008. Impact of Parental Stress on Their Relationship with Teenage Children. Home Comm. Sci. 2(1): 51-57. 